\title{
IDENTIFIKASI KUANTITAS SiSWA YANG MisKONSEPSi MENGgUNAKAN Three Tier-Test Pada Materi Gerak Lurus Berubah Beraturan (GLBB)
}

\author{
Putri Retno Artiawati1), Riski Muliyani ${ }^{2)}$, Yudi Kurniawan ${ }^{2)}$ \\ 1) Program Studi Pendidikan Fisika, STKIP Singkawang \\ E-mail: putriretnoartiawati@gmail.com \\ 2) Program Studi Pendidikan Fisika, STKIP Singkawang \\ E-mail: kikiriski1012@gmail.com \\ 2) Program Studi Pendidikan Fisika, STKIP Singkawang \\ E-mail: yudikurniawan1012@gmail.com
}

\begin{abstract}
Abstrak. Penelitian ini bertujuan untuk mengidentifikasi kuantitas siswa yang miskonsepsi pada materi Gerak Lurus Berubah Beraturan (GLBB). Terdapat dua konsep distribusi atau sebaran miskonsepsi pada materi GLBB. Jenis penelitian ini adalah penelitian deskriptif kuantitatif dengan teknik pengambilan sampel adalah purposive sampling. Instrumen penelitian yang digunakan adalah three tier-test. Hasil dari penelitian menunjukkan bahwa miskonsepsi tertinggi adalah miskonsepsi benda yang memiliki massa lebih besar, apabila dijatuhkan dari ketinggian y ang sama, maka benda tersebut akan tiba terlebih dahulu ke dasar. Hasil dari penelitian ini dapat digunakan untuk mencari solusi dalam menurunkan kuantitas siswa yang miskonsepsi. Tujuan dari penelitian ini adalah unt uk mengidentifikasi kuantitas siswa y ang miskonsepsi pada materi GLBB.
\end{abstract}

Kata Kunci: Kuantitas Siswa yang Miskonsepsi; Miskonsepsi; Three Tier-Test; Gerak Lurus Berubah Beraturan (GLBB)

\section{Pendahuluan}

Konsep fisika sebenarnya sudah mulai tumbuh sejak kecil melalui pengamatan yang dialami [1]. Seiring berjalannya waktu, konsep yang dipelajari berasimilasi dengan kebiasaan sehari-hari, sehingga terjadi ketidaksesuaian konsep atau miskonsepsi [2]. Istilah miskonsepsi terkait dengan konsepsi siswa yang berbeda dengan konsep ilmiah yang diterima secara umum [3]. Miskonsepsi didefenisikan sebagai konsepsi yang dipegang kuat dan merupakan struktur kognitif yang stabil namun tidak sama dengan konsepsi para ahli atau konsep ilmiah. Adanya miskonsepsi yang terjadi pada siswa dapat menghambat dalam penerimaan pengetahuanpengetahuan baru sehingga akan menghalangi keberhasilan sis wa dalam belajar [4].

Miskonsepsi sulit untuk diperbaiki dan seringkali siswa yang sudah dapat mengatasi miskonsepsi beberapa bulan kemudian dapat mengulangi miskonsepsi [5]. Untuk mengatasi miskonsepsi siswa adalah mencari bentuk kesalahan atau miskonsepsi yang dimiliki siswa, kemudian mencari penyebab dan menentukan treatment yang tepat untuk mengurangi miskonsepsi [6]. Pada penilitian ini peneliti akan mengungkapkan atau mengidentifikasi miskonsepsi pada materi Gerak Lurus Berubah Beraturan (GLBB) : kecepatan dan percepatan selalu memiliki arah yang sama, benda yang memiliki massa lebih besar apabila dijatuhkan dari ketinggian yang sama akan tiba terlebih dahulu dibandingkan massa yang lebih kecil ke tanah. Terdapat beberapa langkah yang dapat digunakan untuk mengatasi miskonsepsi yaitu, mencari atau mengungkap miskonsepsi, menemukan penyebabnya dan mencari solusi untuk mengatasi miskonsepsi [6]. Pada penelitian peneliti memilih langkah pertama yaitu mengungkap miskonsepsi pada siswa. Peneliti berharap hasil penelitian ini dapat digunakan untuk penelitian berikutnya untuk menemukan penyebab terjadinya miskonsepsi.

Miskonsepsi adalah kegagalan dalam menghubungkan atau menjelaskan peristiwa yang ada di sekitar dengan konsep dimiliki [7]. Miskonsepsi dapat dilihat pada konsep yang tidak cocok dengan konsep ilmiah. Miskonsepsi dikarenakan adanya kesalahan informasi yang menyebabkan kekeliruan dalam pemahaman konsep dan pemikiran [8]. Istilah miskonsepsi terkait dengan konsepsi siswa yang berbeda dengan konsep ilmiah yang diterima secara umum [3]. 


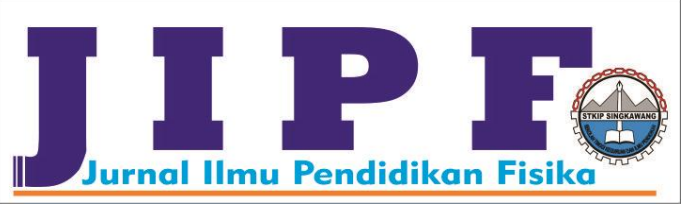

Miskonsepsi didefenisikan sebagai konsepsi yang dipegang kuat dan merupakan struktur kognitif yang stabil namun tidak sama dengan konsepsi para ahli atau konsep ilmiah. Berdasarkan pengertian yang telah dijabarkan oleh para peneliti dapat disimpulkan bahwa miskonsepsi adalah kekeliruan dalam memahami konsep materi pembelajaran yang dapat menyebabkan ketidakcocokkan antara konsep yang dimiliki oleh pribadi dengan konsep ilmiah.

Three tier-test merupakan satu diantara tes diagnostik yang digunakan untuk mengidentifikasi miskonsepsi dan pemahaman konsep [8]. Three tie-test berguna untuk mengetahui jawaban siswa yang salah dan miskonsepsi [9]. Three tier-test memiliki tiga tingkatan yaitu pada tingkat pertama adalah pengujian tentang pengetahuan berupa pilihan ganda. Tingkat kedua, alasan siswa dalam memilih jawaban. Tingkat ketiga adalah keyakinan siswa dalam memilih jawaban [7]. Three tier-test dapat digunakan bagi guru maupun peneliti untuk mengetahui atau mengungkap miskonsepsi yang dialami oleh siswa.

\section{METODE PENELITIAN}

Jenis penelitian yang digunakan pada penelitian ini adalah deskriptif kuantitatif dan hasil dari penelitian ini adalah gambaran mengenai jumlah kuantitas siswa yang miskonsepsi pada materi Gerak Lurus Beraturan (GLB). Populasi penelitian in i adalah seluruh siswa kelas $X$ di salah satu SMA Negeri Kota Singkawang. Teknik pengambilan sampel pada penelitian ini adalah purposive sampling, teknik pengambilan sampel dengan pertimbangan tertentu yaitu siswa yang telah mempelajari materi Gerak Lurus Berubah Beraturan (GLBB). Jumlah sampel pada penelitian ini adalah 30 orang siswa. Terdapat beberapa keputusan dalam three tier-test. Berikut adalah tabel keputusan dalam three tier-test yang diadopsi dari Kurniawan dkk [9].

TABEL 1

KEPUTUSAN THREE TIER-TEST

\begin{tabular}{cccc}
\hline Jawaban Siswa & Tingkat 1 & Tingkat 2 & Tingkat 3 \\
\hline Konsep Ilmiah & Benar & Benar & Yakin \\
Miskonsepsi & Benar & Salah & Yakin \\
Miskonsepsi & Salah & Benar & Yakin \\
Miskonsepsi & Salah & Salah & Yakin \\
Guess & Benar & Salah & Tidak yakin \\
Guess & Salah & Benar & Tidak yakin \\
Lucky Guess & Benar & Benar & Tidak yakin \\
Lack of Knowledge & Salah & Salah & Tidak y akin \\
\hline
\end{tabular}

TABEL 2

SEBARAN MISKONSEPSI PADA MATERI GLBB

\begin{tabular}{cl}
\hline No. Konsep & \multicolumn{1}{c}{ Miskonsepsi } \\
\hline Konsep 1 & $\begin{array}{l}\text { Kecepatan dan percepatan selalu memiliki arah } \\
\text { yang sama. }\end{array}$ \\
\hline Konsep 2 & $\begin{array}{l}\text { Benda yang memiliki massa lebih besar apabila } \\
\text { dijatuhkan dari ketinggian yang sama akan tiba } \\
\text { terlebih dahulu dibandingkan massa yang lebih } \\
\text { kecil ke tanah. }\end{array}$ \\
\hline
\end{tabular}

Jurnal Ilmu Pendidikan Fisika

Volume 3 Number 1 month March 2018. Page 5-7 p-ISSN: 2477-5959 e-ISSN: 2477-8451

Penggunaan three tier-test dapat mempermudah dalam mengungkapkan miskonsepsi yang terjadi pada siswa. Pada Tabel 2 berikut, merupakan sebaran miskonsepsi yang dialami oleh siswa yang terdiri dari 2 konsep pada materi GLBB.

\section{HASIL DAN PEMBAHASAN}

Setiap jawaban siswa kemudian dianalisis dan disajikan pada diagram berikut. Persentase kuantitas siswa yang miskonsepsi terdapat pada Gambar 1 berikut.

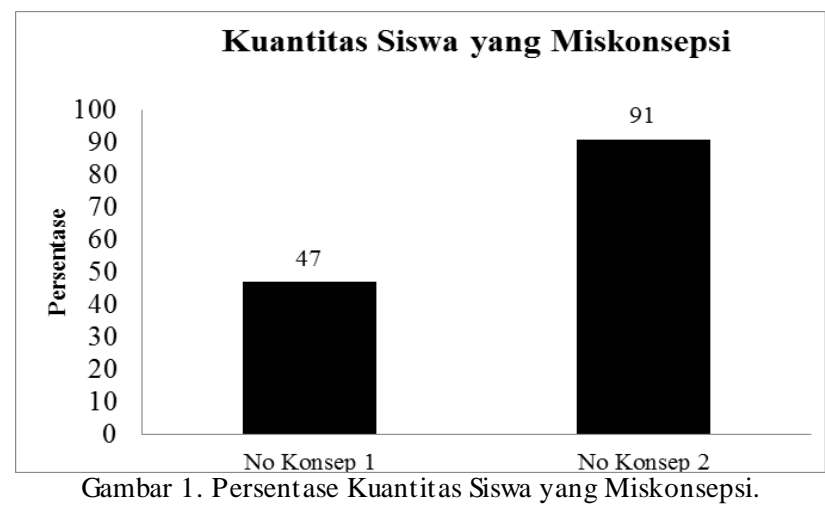

Identifikasi kuantitas siswa yang miskonsepsi pada penelitian ini menggunakan three tier-test. Berdasarkan Gambar 1 kuantitas siswa yang miskonsepsi dengan persentase $91 \%$ pada konsep no 2 yaitu benda yang me miliki massa lebih besar, apabila dijatuhkan dari ketinggian yang sama, maka benda tersebut akan tiba terlebih dahulu ke dasar. Pujianto menyatakan bahwa siswa beranggapan bahwa benda yang lebih berat apabila dijatuhkan dari ketinggian yang sama akan tiba terlebih dahulu ke dasar, padahal konsep sebenarnya tidaklah demikian, dua buah benda yang dijatuhkan dari ketinggian yang sama akan tiba ke dasar secara bersamaan karena jika gesekan udara diabaikan setiap benda yang jatuh akan mendapatkan percepatan tetap yang sama tanpa bergantung pada bentuk maupun berat benda [10]. Sedangkan kuantitas siswa yang miskonsepsi dengan persentase $47 \%$ pada konsep no 1 yaitu kecepatan dan percepatan selalu memiliki arah yang sama. Siswa beranggapan bahwa percepatan benda pada saat vertikal ke atas kecepatan dan percepatannya memiliki arah yang sama, konsep sebenarnya tidak demikian pada saat benda dilemparkan ke atas arah percepatan benda ke bawah (percepatan gravitasi).

\section{KESIMPULAN}

Berdasarkan hasil dari analisis data yang dilakukan, dapat disimpulkan bahwa miskonsepsi pada materi GLBB terdapat 2 konsep yaitu kecepatan dan percepatan selalu memiliki arah yang sama dengan persentase $47 \%$ dan yaitu benda yang memiliki massa lebih besar, apabila dijatuhkan dari ketinggian yang sama, maka benda tersebut akan tiba terlebih dahulu ke dasar dengan persentase $91 \%$. Diharapkan hasil dari penelitian ini dapat dijadikan referensi untuk penelitian selanjutnya untuk ditemukan penyebab maupun solusi dari miskonsepsi tersebut. 


\section{DAFT AR PUST AKA}

[1] Pertiwi, C.A., Setyarsih, W. 2015. Konsepsi Siswa Tentang Pengaruh Gaya pada Gerak Benda Menggunakan Instrumen Force Concept Inventory (FCI) Termodifikasi. Jurnal Inovasi Pendidikan Fisika (JIPF), Vol 4 No 2.

[2] Rosdianto, H., Murdani, E., \& Hendra. 2017. The Implementation of POE (Predict Observe Explain) Model to Improve Student's Concept Understanding on Newton's Law. Jurnal Pendidikan Fisika, Vol 6 No 1: 55-57.

[3] Yuliana, R., Karyanto, P., \& Marjono. 2013. Pengaruh Pemanfaatan Concept Map dalam Model Kontruktiv isme Tipe Novick terhadap Miskonsepsi pada Konsep Sistem Pernapasan Manusia. BIO-PEDAGOGI, Vol 2 No 2.

[4] Tayubi, Y.R. 2005. Identifikasi Miskonsepsi pada Konsep-Konsep Fisika Menggunakan Certainty of Response Index (CRI). Mimbar Pendidikan, No 3.

[5] Hamdani. 2013. Deskripsi Miskonsepsi Siswa Tentang Konsep-Konsep dalam Rangkaian Listrik. Jurnal Pendidikan Matematika dan IPA, Vol 4 No 1.

[6] Suparno, P. 2005. Miskonsepsi dan Perubahan Konsep dalam Pendidikan Fisika. Jakarta: PT Grasindo.

[7] Kurniawan, Y., Suhandi, A. 2015. The Three-Tier Test for Identification The Quantity of Student's Misconception on Newton's First Law. Globallluminators Publishing, Vol 2.

[8] Muliyani, R,. Kaniawati, I. 2015. Identification of Quantity Student's Misconception on Hydrostatic Pressure With Three Tier-Test. GlobalIlluminators Publishing, Vol 2.

[9] Kurniawan, Y., Suhandi, A., \& Hasanah, L. 2016. The Influence of Implementation of Interactive Lecture Demonstrations (ILD) Conceptual Change Oriented Toward The Decreasing of The Quantity Students That Misconception on The Newton's First Law. AIP Conference Proceedings.

[10] Pujianto, A., Nurjannah, \& Darmadi, I.W. 2014. Analisis Konsepsi Siswa pada Konsep Kinematika Gerak Lurus. Jurnal Pendidikan Fisika Tadulako (JPFT), Vol 1 No 1. 